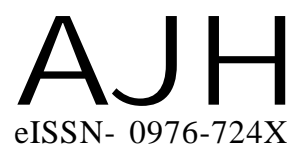

Article history :

Received : 11.04.2014

Revised : 27.09.2014

Accepted : 13.10 .2014
Author for correspondence : BHUPINDER SINGH THAKUR Regional Horticultural Research Station, Dr. Y.S. Parmar University of Horticulture and Forestry, Bajaura, KULLU (H.P.) INDIA

Email : bhupindert@gmail.com
THE ASIAN JOURNAL OF HORTICULTURE

Volume 9 | Issue 2 |Dec., 2014|319-323

Visit us -www.researchjournal.co.in

\title{
Studies on effect of temperature on curd yield under year round production system of cauliflower (Brassica oleracea var. botrytis L.) under mid hills of Himachal Pradesh
}

\section{BHUPINDER SINGH THAKUR}

ABSTRACT : The cauliflower groups early var. 'Pusa Himjyoti', mid late variety 'Swati' and late group variety 'PSB K-1' were planted at a gap of one month at different planting dates for two consecutive years during 2009-10 and 2010-11 to find out the effect of varying temperatures on net curd yield and other associated characters in each maturity group. The varieties varied in their performance for net curd yield as per the maturity group and temperature regime and it was found that early maturing varieties gave high net curd yield under high temperature planting dates, whereas, mid late and late maturing varieties gave high net curd yield under the mild temperature regimes. Curd diameter in early cauliflower was found to be maximum under increasing temperatures, whereas, mild temperature range helped in producing maximum curd size in mid group variety. Late group variety also produced maximum curd diameter when temperature increased from freezing to $10-15^{\circ} \mathrm{C}$. The plant leaf number per plant was found to be maximum under higher temperatures for all the maturity group varieties. Cauliflower curds irrespective of maturity group took more time to maturity at lower temperature regimes as compared to the high temperature regimes for every maturity group and planting date. The best production cycle for year round production of cauliflower in the mid hills was, therefore, found to be June-July (early group); October (late group); followed by February planting of mid late group varieties which can give higher net curd yield besides ensuring best quality curd supply to the markets.

KEY WORDS : Temperature, Regime, Cauliflower, Location, Planting date

HOW TO CITE THIS ARTICLE : Thakur, Bhupinder Singh (2014). Studies on effect of temperature on curd yield under year round production system of cauliflower (Brassica oleracea var botrytis L.) under mid hills of Himachal Pradesh. Asian J. Hort., 9(2) : 319-323. 